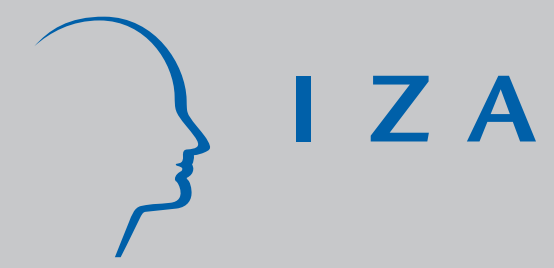

IZA DP No. 131

Are Immigrants Favorably Self-Selected?

An Economic Analysis

Barry R. Chiswick

March 2000 


\title{
Are Immigrants Favorably Self-Selected? An Economic Analysis
}

\author{
Barry R. Chiswick \\ University of Illinois at Chicago and IZA, Bonn
}

Discussion Paper No. 131
March 2000

IZA

P.O. Box 7240

D-53072 Bonn

Germany

Tel.: +49-228-3894-0

Fax: +49-228-3894-210

Email: iza@iza.org

This Discussion Paper is issued within the framework of IZA's research area Mobility and Flexibility of Labor Markets. Any opinions expressed here are those of the author(s) and not those of the institute. Research disseminated by IZA may include views on policy, but the institute itself takes no institutional policy positions.

The Institute for the Study of Labor (IZA) in Bonn is a local and virtual international research center and a place of communication between science, politics and business. IZA is an independent, nonprofit limited liability company (Gesellschaft mit beschränkter Haftung) supported by the Deutsche Post AG. The center is associated with the University of Bonn and offers a stimulating research environment through its research networks, research support, and visitors and doctoral programs. IZA engages in (i) original and internationally competitive research in all fields of labor economics, (ii) development of policy concepts, and (iii) dissemination of research results and concepts to the interested public. The current research program deals with (1) mobility and flexibility of labor markets, (2) internationalization of labor markets and European integration, (3) the welfare state and labor markets, (4) labor markets in transition, (5) the future of work, (6) project evaluation and (7) general labor economics.

IZA Discussion Papers often represent preliminary work and are circulated to encourage discussion. Citation of such a paper should account for its provisional character. 
IZA Discussion Paper No. 131

March 2000

\section{ABSTRACT \\ Are Immigrants Favorably Self-Selected? An Economic Analysis}

This paper explores the theoretical issues and the empirical literature regarding the selectivity of migrants. Although the primary focus is on international migration, reference is made to internal migration and return migration. The theoretical analysis indicates a tendency toward the favorable self-selection (supply) of migrants for labor market success. The favorable selectivity is more intense the greater the out-of-pocket (direct) costs of migration and return migration, the greater the effect of the higher level of ability on lowering the costs of migration, and the smaller the relative skill differentials in the lower-wage origin relative to the higher-wage destination. Favorable selectivity for labor market success can be expected to be less intense for non-economic migrants, such as refugees, tied movers and ideological migrants, and for sojourners (short-term migrants) and illegal aliens.

Among countries for whom entry restrictions are binding, the criteria for rationing immigration visas (demand) will influence the favorable selectivity of those who actually immigrate. Selection criteria can ration visas on one or more characteristics that enhance labor market earnings (e.g., education), or on characteristics that are seemingly independent of skill level (e.g., kinship ties). Under either criteria there will be a tendency for immigrants to be favorably selected, although this is less intense under the later criteria. The overall favorable selectivity of immigrants, therefore, depends on the favorable selectivity of the supply of immigrants and the criteria used to ration admissions.

JEL Classification: J61, J15, J24, J31

Keywords: Immigrants, migration, selectivity, human capital, earnings

Barry R. Chiswick

Department of Economics

University of Illinois at Chicago

601 South Morgan Street

Chicago, IL 60607-7121

USA

Tel.: +1-312-996-2683

Fax: +1-312-996-3344

Email: brchis@uic.edu 


\section{Introduction}

Economic migrants are those who move from one place of work and residence to another, either within a country or across international boundaries, primarily because of their own economic opportunities, as distinct from refugees and those who move because of the migration decisions of others ("tied movers"). One of the standard propositions in the migration literature is that economic migrants tend to be favorably "self-selected" for labor market success. That is, economic migrants are described as tending, on average, to be more able, ambitious, aggressive, entrepreneurial, or otherwise more favorably selected than similar individuals who choose to remain in their place of origin. The favorable selectivity for labor market success of migrants would be less intense among those for whom other motives are important in their migration decision, such as tied movers, refugees, and those who move for ideological reasons ("ideological migrants").

Whether migrants are favorably selected or not is important for understanding the economic and sociological consequences of migration for the sending (origin) and receiving (destination) regions, as well as for the migrants themselves. The more highly favorably selected are migrants the more successful will be their adjustment in the destination, and the more favorable their impact on the destination economy and society. Moreover, the more highly favorably selected are the migrants the greater, in general, will be the adverse effect of their departure on their origin. As a consequence, the extent of the favorable selectivity of migrants will effect the immigration policies of the destination and emigration policies of the origin. Immigration history, and as a result, the histories of the origin and destination regions are thereby influenced by the selectivity of migrants. 
In recent years there have been challenges to the general proposition of the favorable selectivity of migrants. In addressing this issue this paper first develops the human capital model for migration (Section II). It then considers (Section III) alternative specifications of the migration model that are relevant for the issue of migrant selectivity. A review of some of the existing literature forms the basis for the discussion of the empirical testing of the model of migrant selectivity. The paper closes with a summary and conclusion (Section IV).

\section{The Human Capital Migration Model}

Consider a simple human capital model of investment in migration (Sjaastad 1962, Becker 1964). Assume that wages in the origin and destination do not vary with the level of labor market experience. That is, for simplicity of exposition, it is assumed there is no on-thejob training and there are no post-migration human capital investments after the investment period. Also assume that there is a very long (infinite) work life, and that the costs of migration occur in the first period. ${ }^{1}$ These migration costs include foregone earnings $\left(\mathrm{C}_{\mathrm{f}}\right)$ and direct or outof-pocket costs $\left(\mathrm{C}_{d}\right)$. Migration costs are defined broadly to include not merely the airfare or bus ticket and time in transit, but the full costs of relocating and adjusting both consumption and labor market activities from the origin to the destination. ${ }^{2}$ The rate of return from migration can then be written (approximately) as:

$$
r=\frac{W_{b}-W_{a}}{C_{0}+C_{d}}
$$

where $\mathrm{W}_{\mathrm{b}}$ represents earnings in the destination and $\mathrm{W}_{\mathrm{a}}$ represents earnings in the origin. 
Migration occurs if the rate of return from the investment in migration (r) is greater than or equal to the interest cost of funds for investment in human capital (i). The interest costs of funds is lower, the greater the person's wealth and access to the capital market. ${ }^{3}$

Assume first there are two types of workers, low ability and high ability workers, and that these ability levels are known without cost to the workers and potential employers. ${ }^{4}$ The more able may have more innate ability or merely more schooling. Ability may have many dimensions, including ambition, intelligence, learning speed, entrepreneurial skills, aggressiveness, tenacity, etc. Let $r_{1}$ be the rate of return from migration to a low ability person and let $r_{h}$ be the rate of return to a high ability person. If the low and high ability individuals have the same interest cost of funds, the person with the higher rate of return from migration will have the greater propensity to migrate. As a first step, assume that in the origin and destination wages are $100 \mathrm{k}$ percent higher for the more able, that is, the ratio of wages in the destination to wages in the origin is independent of level of ability. Then,

$$
\begin{gathered}
W_{b, h}=(1+k) W_{b, l}, \\
\text { and } \\
W_{a, h}=(1+k) W_{a, l},
\end{gathered}
$$

It is assumed that direct costs, which are the out-of-pocket costs associated with migration, do not vary with ability, $C_{d, h}=C_{d, l}$. Also assume that greater ability has no effect on efficiency in migration, but it does raise the value of foregone earnings. Then $C_{f, h}=(1+k) C_{f, l}$, where $C_{f}$ is the foregone earnings. The rate of return to the high ability person can be written as: 


$$
r_{h}=\frac{(1+k) W_{b, l}-(1+k) W_{a, l}}{(1+k) C_{f, l}+C_{d}}=\frac{W_{b, l}-W_{a, l}}{C_{f, l}+\frac{C_{d}}{(1+k)}}
$$

Thus, the rate of return to the high ability person $\left(r_{h}\right)$ is greater than the rate of return to the lowest ability person $\left(\mathrm{r}_{l}\right)$ as long as earnings increase with ability $(\mathrm{k}>0)$ and there are positive outof-pocket costs of migration $\left(\mathrm{C}_{d}>0\right)$.

If there were no out of pocket costs associated with migration $\left(C_{d}\right.$ equals zero), then $r_{h}=$ $\mathrm{r}_{l}$, and there would be no selectivity in migration on the basis of ability. Alternatively, suppose there were no labor market premium for a higher level of ability or a particular dimension of ability $(\mathrm{k}=0)$. That is, this dimension of ability was not relevant in the labor market. Then, $\mathrm{r}_{h}=\mathrm{r}_{l}$, and there is no selectivity in migration on the basis of this dimension of ability. The smaller are the direct costs of migration $\left(\mathrm{C}_{d}\right)$ relative to the wage premium for higher levels of ability $(1+\mathrm{k})$, the smaller is $\frac{C_{d}}{(1+k)}$, and hence the smaller is the differential in the rate of return to those of higher ability relative to those of lesser ability.

The preceding model assumed that greater ability enhances efficiency in the labor market in both the origin and destination. Now let us add another assumption: The more able are also more efficient in migration. Just as higher ability enhances productivity in the labor market these same characteristics may enhance efficiency in investment in human capital. The same investment in migration may require fewer units of time and/or fewer units of out-of-pocket costs for the more able.

Since the opportunity cost of migration $\left(\mathrm{C}_{f}\right)$ is the product of time units $(\mathrm{t})$ involved in migration multiplied by the value of time in the origin $\left(\mathrm{W}_{a}\right)$, opportunity costs can be written as 
$\mathrm{C}_{f}=\mathrm{tW}{ }_{a}$. Efficiency can be expressed as the more able needing fewer time units to accomplish the same task $\left(\mathrm{t}_{h}<\mathrm{t}_{l}\right)$. Then, $\mathrm{C}_{\mathrm{f}, l}=\mathrm{t}_{l} \mathrm{~W}_{\mathrm{a}, l}$ and $\mathrm{C}_{f, h}=\mathrm{t}_{h} \mathrm{~W}_{a, h}=\mathrm{t}_{h}(1+\mathrm{k}) \mathrm{W}_{a, l}$, where $\mathrm{t}_{h}<\mathrm{t}_{l}$. This strengthens the argument that $r_{h}$ is greater than $r_{l}$.

Note that even if there are no out-of-pocket costs $\left(\mathrm{C}_{d}=0\right)$, if the more able are more efficient in using time, relative skill differentials that do not vary across regions generate favorable selectivity in migration. That is, if $\mathrm{C}_{d}=0$, and $\mathrm{t}_{h}<\mathrm{t}_{l}$, using equation (3), when $\mathrm{C}_{\mathrm{f}, l}=$ $\mathrm{t}_{l} \mathrm{~W}_{\mathrm{a}, l}$ and $\mathrm{C}_{f, h}=\mathrm{t}_{h}(1+\mathrm{k}) \mathrm{W}_{\mathrm{a}, l}$, then it follows that $\mathrm{r}_{h}>\mathrm{r}_{l}$.

The more able may also be more efficient in utilizing out-of-pocket expenditures $\left(\mathrm{C}_{d, h}<\right.$ $\left.\mathrm{C}_{d, l}\right)$ incurred in migration, just as they are more efficient in other activities. If direct costs exist and they are smaller for the more able $\left(\mathrm{C}_{d, h}<\mathrm{C}_{d, l}\right)$, the difference in the rate of return from migration is even greater than if there were no ability differences in using the out-of-pocket expenditures required for migration. If $C_{d, h}=(1+\lambda) C_{d, l}$ where $\lambda$ is a direct cost efficiency parameter, and $\lambda<0$, then

$$
r_{h}=\frac{W_{b, l}-W_{a, l}}{C_{f, l}+\frac{C_{d, l}(1+\lambda)}{(1+k)}},
$$

and $r_{h}$ is larger relative to $r_{l}$ the greater the efficiency in handling direct costs (the larger is $\lambda$ in absolute value).

Thus, a human capital model which assumes relative skill differentials are the same in the origin and destination generates favorable selectivity of migration in the supply of migrants if there are out of pocket (direct) costs that are not proportional to wages. This favorable selectivity 
is more intense if those who are more able in the labor market are also more efficient (able) in the migration process, either in using their own time or in using out-of-pocket expenditures.

It is reasonable to assume, however, that migrants will differ in the combination of own time (forgone earnings) and purchased inputs (direct costs) in the migration and readjustment process. The greater the value of forgone earnings (wages) and the greater a person's efficiency in using purchased inputs relative to their own time, the greater will be the relative use of purchased inputs over own time. Thus, high ability migrants may appear to spend more on the migration process (out-of-pocket expenditures) and to use less time than those of lesser ability.

The model can be extended to consider situations in which the relative wage differentials are not the same across countries. Assume that there are no direct costs of migration $\left(\mathrm{C}_{d}=0\right)$ and that ability (human capital) does not effect efficiency in time use in migration $\left(t_{h}=t_{l}\right)$. Then,

$$
r_{l}=\frac{W_{b, l}-W_{a, l}}{t W_{a, l}}=\frac{1}{t}\left(\frac{W_{b, l}}{W_{a, l}}-1\right)
$$

and

$$
r_{h}=\frac{W_{b, h}-W_{a, h}}{t W_{a, h}}=\frac{1}{t}\left(\frac{W_{b, h}}{W_{a, h}}-1\right)
$$

Then the ratio of wages in the destination relative to the origin determines migration incentives. If the ratio of wages is the same, the rates of return are the same and there is no skill selectivity in migration. If the ratio of wages across regions is greater for the high ability, that is, $W_{b} / W_{a}$ is greater for $\mathrm{h}$ than for 1 , the high ability have a greater incentive to migrate. If on the other hand, the ratio of wages across regions is greater for the low ability, they would have a greater propensity to migrate, other things being the same. 
Several implications follow from this human capital model regarding the favorable selectivity of economic migrants, that is, those basing their migration decision on the conventionally measured rate of return from migration. The larger are the out-of-pocket costs of migration, the lower is the propensity to migrate, but the lower is the return migration rate and the greater is the propensity for favorable selectivity in migration. ${ }^{5}$ This propensity for favorable selectivity is intensified if those who are more efficient in the labor market are also more efficient in the migration and adjustment process. This effect occurs if migrants are more efficient in using their own time, in using purchased inputs, or in combining their time and purchased inputs. If those with more human capital, for example, those with more schooling and greater proficiency in destination language skills, are more efficient in obtaining and interpreting information and in making decisions (greater allocative efficiency), they would be more efficient in the migration process (Schultz 1975).

The favorable selectivity of migrants is even greater if the relative wage differential between the destination and origin (the ratio of wages in the destination to those in the origin) is greater for the high ability workers. The favorable selectivity is less intense if the ratio of wages in the destination to those in the origin is smaller for the high ability. Only if this latter effect is sufficiently large to offset the favorable selectivity effects of out-of-pocket costs and greater efficiency in the migration process will there be no selectivity in migration. In this framework, for there to be negative selectivity in migration even more compressed wage differentials across regions are required for the high ability relative to the low ability.

\section{Alternative Models}

Several alternatives to the simple human capital model presented in Section II have 
appeared in the literature to address the issue, either directly or indirectly, of the favorable selectivity of migrants. These include models based on asymmetric information, temporary migration, the Roy model, and non-economic determinants of migration.

\section{A. Asymmetric Information}

Katz and Stark (1984, 1987) present a model of asymmetric information. Suppose potential migrants know their true productivity and employers in the origin have, over time, learned the workers' true productivity. Employers in the destination, however, cannot differentiate among high ability and low ability migrants. Employers in the origin pay workers wages in accordance with the worker's true productivity, while those in the destination pay workers according to the expected (average) productivity of migrants. High ability workers will experience a smaller wage differential and higher foregone earnings than low ability workers, and they will therefore have a smaller incentive to migrate. If employers can never detect true ability differences among migrant workers there would be adverse selection. The increase in low ability migration relative to high ability migration would drive down the expected wage of migrants in the destination, further discouraging high ability migration.

Employers in the destination would, of course, have an incentive to develop tests or techniques for distinguishing high ability from low ability workers. The lower the cost and the shorter the time interval for identifying ability, the lower the adverse selection effect from asymmetric information. Asymmetric information would appear to be most compelling for lowskilled jobs with a short duration (tenure on the job) that do not involve repeat occurrences. High wage jobs would warrant investment in information about ability, if only through a trial investment/working period. This might take the form of hiring immigrant workers at low wages 
until true ability levels are revealed. Employers would then be able to discern the ability level of workers for jobs that have a long tenure or that involve repeat occurrences.

\section{B. Short Term Migrants}

The model developed in Section II assumed, for simplicity, that workers remained in the destination for a long period of time and it implicitly assumed away location-specific human capital. Suppose, however, there is a short expected duration in the destination because of high expectations of voluntary return migration (guest worker or sojourner migration) or involuntary return migration (deportations) (Chiswick 1980, 1986b). Then migrants who made investments in destination-specific human capital would experience a capital loss when they leave the destination and their origin-specific human capital would have depreciated during their sojourn. Therefore, sojourner migrants or illegal aliens who are concerned about apprehensions and deportations would tend to avoid country-specific human capital investments and would tend to invest in internationally transferable human capital or very little human capital.

To the extent that there is a complementarity between country-specific and internationally transferable human capital, which is increased by location-specific licensing and certifications for professional and skilled jobs, temporary migrants would tend to have lower levels of both forms of human capital. This would result in lower skill levels among sojourner migrants and illegal aliens than among long term (permanent) legal migrants. This would give the appearance of less positive self-selectivity among short-term migrants (guest workers, sojourners and illegal aliens) compared to permanent legal migrants. ${ }^{6}$

\section{The Roy Model - Relative Skill Differentials}

In a series of studies on selectivity in migration Borjas $(1987,1991)$ presents the Roy 
model (Roy 1951) as an alternative specification of the human capital model. ${ }^{7}$ It is implicitly assumed that all migration costs are a constant proportion of foregone earnings, that there are no fixed (out-of-pocket) costs, and that ability has no effect on efficiency in migration. As a result, migration incentives are a function of the ratio of wages in the destination to the origin, as shown above in equations (5) and (6) in Section II.

This application of the Roy model is a special case of the human capital model, as shown in Section II. For the same wage structure (relative skill differentials) in the destination, a larger relative skill differential in the lower income origin implies a smaller destination to origin wage differential for higher skilled workers, and hence a smaller incentive to migrate compared to lower-skilled workers. The reverse follows if there is a smaller relative skill differential in the origin. Borjas (1987:552) writes that: "If the income distribution in the sending country is more unequal than that of the United States (and the correlation in earnings is positive and strong), emigrants will be chosen from the lower tail of the income distribution in the country of origin". This is not quite correct. As shown above, a larger skill differential in the origin than in the destination does not necessarily imply negative selectivity, but rather only less favorable positive selectivity.

In an empirical test of this model, Borjas (1987) regresses initial immigrant earnings and the improvement in immigrant earnings, as well as the emigration rate from the origin, on a measure of relative skill differentials in the origin. The measure of relative skill differentials Borjas used is the "Ratio of household income of the top 10 percent of the households to the income of the bottom 20 percent of the households" (Borjas 1987:545). This actually does not test for the effect of income inequality on positive or negative selectivity in international 
migration, but only for whether inequality in income in the origin is associated with a greater or lesser degree of selectivity, after controlling for other variables that reflect the effects on earnings in the United States of positive selectivity. This measure of household income inequality may be poorly related to the relevant variable, relative skill differentials. Controlling for other variables, the coefficient on the inequality variable is not statistically significant in analyses of immigrant earnings in the United States and in half of the specifications has a positive rather than the expected negative sign. Contrary to the conclusion, the test does not offer support for the hypothesis that immigrants from countries with greater skill differentials are drawn from the least able members of the origin labor force. ${ }^{8}$

In his reply to the Jasso and Rosenzweig (1990) critique of his paper, Borjas (1990:306) repeats that "If earnings between the United States and the source country are positively and strongly correlated, positive selection is observed whenever the United States has more income inequality then the source country and negative selection is observed otherwise". In his new empirical test Borjas (1990, p.307) uses as his measure of relative skill differentials a dummy variable for whether the origin country has an income distribution more unequal than the United States. The t-ratio of -1.8 is at the margin of statistic significance, although Borjas asserts confidently that his prediction is "confirmed by the results" (Borjas 1990:308). It is not clear why he changed the measure of inequality to a dichotomous variable or whether this measure of inequality in this and in the earlier study reflects skill differentials or other dimensions of household income inequality, such as the inequality in human capital and other assets, or differences in household labor supply. Moreover, the marginal t-ratio for inequality is in contrast to the very high t-ratios for the effect on immigrant earnings in the United States of origin 
country per capita income $(\mathrm{t}=6.4)$ and the refugee variable, whether the origin is a communist country $(\mathrm{t}=-3.6)$.

\section{Non-Economic Migrants}

Conventionally defined economic variables are not the only determinants of migration. People also move for "non-economic" reasons, including to accompany or join family members ("tied movers"), for real or perceived threats to their freedom or safety because of their class, religion, race, or other characteristic ("refugees"), and for ideological (including religious) reasons. ${ }^{9}$ The favorable self-selectivity for labor market success would be expected to be less intense among those for whom migration is based primarily on factors other than their own labor market success. Studies of tied movers and refugees in comparison to economic migrants indicate that the former have higher unemployment rates and lower earnings than statistically comparable economic migrants (Mincer 1978; Chiswick 1978, 1979, 1980, 1982). The earnings disadvantages of tied movers and refugees are greater initially and diminish with duration of residence, but generally do not disappear.

\section{E. Empirical Studies of Selectivity: Migrants and Return Migrants}

A variety of studies have been conducted to test directly for the favorable-selectivity of migrants. A series of studies on internal migration in the United States and Canada have found that migrants tend to have higher levels of schooling than non-migrants who remain in the place of origin and that the use of selectivity correction techniques indicates that they would have had higher earnings in the origin than non-movers (see, for example, Islam and Choudhury 1990; Robinson and Tomes 1982; DaVanzo 1976; Vandercamp 1977; Gabriel and Schmitz 1995; Bailey 1993). 
There is less research on the issue of the selectivity of the emigration of in-migrants, of which a special case is return migrants, that is, those who return to their origin. Migrants have a higher propensity for a subsequent move than do non-migrants, other variables being the same. The former have already demonstrated a propensity to move, and have less human and social capital specific to the initial destination. Return migrants may have human and social capital specific to the origin that has not fully depreciated in their absence. Migrants may depart for a number of reasons, including new information about even better opportunities elsewhere, because ex post there is a realization that the destination did not live up to their expectations, or because economic or political circumstances in the origin or in the destination have changed. Moreover, they may depart because the initial move was intended to be temporary (sojourners), perhaps because they are target earners in the destination. These arguments and the statistical analyses suggest that on average migrants who subsequently emigrate will be somewhat less favorably selected than the original flow of economic migrants, but they appear to be more favorably selected than those who never moved..$^{10}$

Beenstock (1996) studied the return migration of immigrants in Israel and found that it was greatest among those from the high income Western democracies who were less successful in adjusting to Israel, among those who migrated as young adults and who did not have children. Return migrants had a lower proficiency in Hebrew (a destination-specific skill) and higher unemployment, other things the same, before they departed. Immigrants to Israel from the highincome Western democracies, primarily ideological migrants, have a high opportunity cost of remaining in Israel.

DaVanzo (1976) finds that for internal migration in the United States the return migrants 
respond to many of the same economic incentives as did the original migrants. Long and Hansen's (1977) study of black return migrants to the South suggests that both the original and return migration were selective in favor of those with more schooling. Rogers (1982) cites data indicating a variety of motives for return migration, including an original intention that the initial migration is only temporary. In an analysis of short-term inter-provincial return migrants in Canada, Vanderkamp (1972) suggests that they were the less successful migrants. In a study of internal migration in the United States using the National Longitudinal Survey of Youth, Bailey (1993) finds a larger positive effect of a college education on initial migration than on return migration. He interprets this as implying that those with higher levels of education not only have higher rates of migration but also make fewer errors in their initial migration, suggesting greater efficiency in migration.

Nearly all of the studies of the selectivity of migrants focus on the level of earnings or schooling of migrants compared to non-migrants in the origin or destination. Two exceptions are studies by Tidrick (1971) and Finifter (1976). Tidrick conducted a survey among Jamaican university students about their intention to emigrate and whether they would encourage others to emigrate. Using cross-tabulations she shows that both propensities were higher, the higher the social class of the student's family and the higher the student's level of ability. Finifter (1976) reports the findings from a series of Gallup Polls conducted in the United States from 1946 to 1971 that included a question on potential interest in emigrating among Americans. The propensity to express an interest in emigrating from the U.S. was greater among males, the currently unemployed, those "dissatisfied with the institutions of the American political system" (ideological emigrants) and those with a higher level of education, and declined with age 
(Finifter, 1976, p 34-35). Both studies find a positive selectivity in the expressed interest in emigrating.

\section{F. The Earnings of Migrants and the Children of Immigrants}

One of the persistent findings regarding immigrants to the United States is that after a period of adjustment of about 10 to 15 years male economic migrants earn more than adult men born in the United States of the same racial/ethnic origin, level of schooling, and other measure characteristics. (See, Chiswick 1979, 1980, 1986a). ${ }^{11}$ Among refugees, on the other hand, initial earnings are lower than among economic migrants, but the rate of improvement is greater and the gap diminishes over time, although it does not disappear with duration of residence. If refugees "catch-up" to the earnings of otherwise similar native born men this catch-up comes later than among economic migrants. Equally striking is that the native-born children of immigrants (second-generation Americans) tend to earn more than the native-born with native born parents (third and higher generation Americans) (Chiswick 1977, 1980, 1986b). Other things the same, within racial and ethnic groups, this earnings advantage is about 5 to 10 percent, or the earnings equivalent of about one extra year of schooling. These earnings advantages of immigrants and their native-born children occur in spite of the disadvantages of a foreign origin, including less country-specific knowledge or information and poorer proficiency in English, especially in the first generation. ${ }^{12}$

An analysis of the earnings of black internal migrants in the United States is instructive. Using data from the 1960 and 1970 Censuses of Population it has been found that black male migrants from the South to states outside of the South display similar earnings patterns as immigrants. The Census provides data on state of birth, state of residence five years ago, and 
current state of residence. Adult black men born in the South who have lived in the non-South, less than 5 years earn significantly less that those born in the non-South, other things being the same. On the other hand, those born in the South who have lived in the non-South five or more years earn significantly more than statistically similar black men who were born in and remained in the non-Southern States. ${ }^{13}$ These findings are consistent with favorable selectivity in migration, with a period of adjustment required in the new (non-South) labor market.

These findings for international and internal migrants are consistent with the hypothesis that economic migrants are favorably self-selected for ability or human capital investment, and that refugees are less intensely self-selected. When the favorable selectivity of economic migrants just outweighs the disadvantages of a "foreign" origin (less destination specific human capital), the earnings of immigrants equal those of the native-born, and then surpasses that of the native born. Some of this favorable self-selectivity is transmitted to the immigrant's native-born children, although presumably with a regression to the mean, that is, the effect is dampened across generations.

\section{Summary and Conclusions}

This paper has explored the theoretical issues and the empirical literature regarding the selectivity of migrants. Although the primary focus is on international migration, reference is made to internal migration and return migration. The analyses indicate a tendency toward the favorable self-selection (supply) of migrants for labor market success on the basis of a higher level of ability broadly defined. The favorable selectivity is more intense: the greater the out of pocket (direct) costs of migration and return migration, the greater the effect of ability on lowering the costs of migration, and the smaller are the wage differences by skill in the lower 
income origin than in the higher income destination. Favorable selectivity for labor market success can be expected to be less intense for non-economic migrants, such as refugees, tied movers and ideological migrants, and for sojourners (short-term migrants) and illegal aliens.

The theoretical analysis in this paper applies only to the supply of immigrants and not to the observed outcomes. The determinants of the demand for immigrants are also relevant for international migration as all nation states have selection criteria for those they will admit. Among countries for whom entry restrictions are binding the criteria for rationing immigration visas will influence the favorable selectivity of those who actually immigrate. Selection criteria can ration visas on one or more characteristics that enhance labor market earnings, such as schooling level, professional qualifications, age, and destination language proficiency, among other criteria. Alternatively, criteria can be used that are seemingly independent of skill level, such as kinship ties, refugee status, and lotteries. There will be a tendency for immigrants to be favorably selected under a given selection criteria. The former criteria, however, are likely to select, on average, a higher ability subset among those who would supply themselves as immigrants than would the latter criteria. The overall favorable selectivity of immigrants, therefore, depends on the favorable selectivity of the supply of immigrants and the criteria used to ration admissions. 


\section{NOTES}

1. Under reasonable discount rates, increases in earnings received far into the future, say starting in 30 years, have a small present value. The length of the effective life can be considered infinite if the decision-maker takes into account the higher earnings their descendants would receive if raised in the destination rather than in the origin. The sharp fall off of migration and other human capital investments with age among adults has less to do with the finiteness of the working life than with the rise in the opportunity cost of time with human capital investment, including on-the-job training or labor market experience, location-specific investments, and the incentive to make the most productive human capital investments (for which the internal rate of return is greater then the discount rate) sooner rather then later.

2. An analysis of the adjustment process is beyond the scope of this paper. The adjustments relevant for the labor market include investments in schooling, on-the-job training, information and language, among other characteristics. See, for example, Chiswick (1978), Chiswick and Miller (1992) and Khan (1997).

3. The interest cost of funds or the discount rate would be the person's borrowing rate if at the margin the person is a borrower and is the lending rate if this is what the person does at the margin. The rate depends on the person's wealth and rate of time preference for consumption in the present relative to the future. Discount rates may therefore vary across individuals and by age for the same individual (See Hirshleifer, 1958). For a model of the supply and demand for investment funds for investments in human capital, see Becker and Chiswick (1966).

4. Although for simplicity of exposition the discussion will be in terms of labor market earnings and ability, it can easily be extended to include efficiency in consumption. For the same nominal earnings, greater efficiency in consumption enhances real earnings.

5. These out-of-pocket costs are frequently measured by distance. See, for example, Schwartz (1973).

6. This is consistent with analyses of illegal aliens in the United States that indicate they are disproportionately low-skilled workers, as measured by their level of educational attainment, English language proficiency, occupational status and earnings. Illegal aliens appear to have lower earnings than workers with legal rights to work who otherwise have similar characteristics, presumably because of their limited job mobility, and shorter expected duration in the destination. See, for example, Rivera-Batiz (1999) and Kossoudji and Cobb-Clark (1998).

7. For a comment and reply on issues other than those raised here, see Jasso and Rosenzweig (1990) and Borjas (1990).

8. Cobb-Clark (1993), however, does find a marginally significant negative relation between income inequality in the origin and the earnings of immigrants in some of her equations in her study of immigrant selectivity among women in the United States. It is surprising that the effect 
is more pronounced for women than for men given that among women there is a larger proportion of tied movers. Given that the inequality measure is household income inequality it is unclear whether female labor supply effects in the origin and destination are determining this relationship.

9. For the classic study of tied-movers and tied-stayers, see Mincer (1978). It is sometimes difficult to distinguish between ideological migrants and refugees. Many of the earliest settlers in the United States came for a fuller expression of their religious beliefs, and not necessarily because of persecution, and hence would be ideological migrants. For a study of ideology and emigration from the United States in the post-WWII period, see Finifter (1976). Americans who went to the Soviet Union in the inter-war period to build the new Soviet State were ideological migrants. North American Jewish immigrants in Israel would also be an example of ideological migrants (Beenstock 1996). While the latter earn more than other immigrants in Israel, overall and other variables the same, their real earnings are lower than what they would have received in the United States (Chiswick, 1998).

10. See, for example, DaVanzo (1983), DaVanzo and Morrison (1986), Herzog and Schlottmann (1983), Long and Hansen (1977), Shumway and Hall (1996), Vandercamp(1972), Yezer and Thurston (1976).

11. Borjas (1985) argues that the appearance of a rise in earnings with duration of residence in cross-sectional data is due to a decline in the quality of more recent cohorts of immigrants. He does not deny the higher ability of earlier cohorts. Using different methodologies, Chiswick (1980, 1986a), Duleep and Regets (1996, 1997a, 1997b) and La Londe and Topel (1992) show that Borjas (1985) misinterpreted the data and that there is no evidence of a decline in the earnings of immigrants relative to natives over successive cohorts during the post-WWII period, other variables being the same. By focusing on immigrant earnings at arrival, Borjas (1985) confused the steepening of human capital earnings profiles for immigrants and natives (a higher return to skill) and a reduction in the transferability of the skills of immigrants due to a shift in source countries of origin with a decline in immigrant quality (ability). For a similar earnings catch-up at the turn of the century, see Blau (1980). For an analysis of the catch-up in terms of employment and unemployment, see Chiswick and Hurst (1998). Lindstrom and Massey (1994) show that the emigration of the foreign born does not distort the assimilation of immigrants observed in the U.S. Census.

12. Preliminary results indicate that among native-born men those who speak a language other than or in addition to English at home, and who are disproportionately second-generation Americans, have lower earnings, other things the same, than the native born who speak only English at home (Chiswick and Miller, 1998).

13. See, for example, Chiswick (1980), Long (1974), Long and Heltman (1975), and Masters (1972). 


\section{BIBLIOGRAPHY}

Bailey, Adrian. 1993. "A Migration History, Migration Behavior and Selectivity," Annals of Regional Science 27: 315-326.

Becker, Gary S. 1964. Human Capital. New York: NBER.

Becker, Gary S. and Barry R. Chiswick, 1996. "Education and the Distribution of Earnings" American Economic Review, 56 (Supplement): 358-69.

Beenstock, Michael. 1996. "Failure to Absorb: Remigration by Immigrants Into Israel," International Migration Review 30: 950-978.

Blau, Francine D. 1980. "Immigration and Labor Earnings in Early Twentieth Century America," IN Julian L. Simon and Julie DaVanzo, eds., Research in Population Economics 2: $21-41$.

Borjas, George J. 1985. "Assimilation, Changes in Cohort Quality and the Earnings of Immigrants," Journal of Labor Economics 3:463-489.

Borjas, George J. 1987. "Self-Selection and the Earnings of Immigrants," American Economic Review 77: 531-553.

Borjas, George J. 1990. "Self-Selection and the Earnings of Immigrants: Reply," American Economic Review 80: 305-308.

Borjas, Geroge J. 1991. "Immigration and Self-Selection,” IN John Abowd and Richard Freeman, eds., Immigration, Trade and the Labor Market, Pp. 29-76. Cambridge: NBER.

Chiswick, Barry R. 1977. "Sons of Immigrants: Are they at an Earnings Disadvantage?" American Economic Review 67:376-380.

Chiswick, Barry R. 1978. “The Effect of Americanization on the Earnings of Foreign-Born Men," Journal of Political Economy 86: 897-922.

Chiswick, Barry R. 1979. "The Economic Progress of Immigrants: Some Apparently Universal Patterns," IN William Fellner, ed., Contemporary Economic Problems, 1979, Pp. 357-399. Washington, D.C.: American Enterprise Institute.

Chiswick, Barry R. 1980. An Analysis of the Economic Progress and Impact of Immigrants. National Technical Information Service, No. PB80-200454. Report prepared for the Employment and Training Administration, U.S. Dept. of Labor. 
Chiswick, Barry R. 1982. The Employment of Immigrants in the United States. Washington: American Enterprise Institute.

Chiswick, Barry R. 1986a. "Is the New Immigration Less Skilled than the Old?" Journal of Labor Economics 4: 168-192.

Chiswick, Barry R. 1986b. "Human Capital and the Labor Market Adjustment of Immigrants: Testing Alternative Hypothesis," Research in Human Capital and Development 4: 1-26.

Chiswick, Barry R. 1998. "Hebrew Language Usage: Determinants and Effects on Earnings Among Immigrants in Israel," Journal of Population Economics 11: 253-271.

Chiswick, Barry R., and Michael Hurst. 1998. "The Labor Market Status of Immigrants: A Synthesis," IN Hermann Kurthen, et al., eds., Immigration, Citizenship and the Welfare State in Germany and the United States: Immigrant Incorporation, Pp. 73-94. Stamford, CT: JAI Press.

Chiswick, Barry R., and Paul W. Miller. 1992. "Language in the Immigrant Labor Market," IN Barry R. Chiswick, ed., Immigration, Language, and Ethnicity: Canada and the United States, Pp. 229-296. Washington D.C.: American Enterprise Institute.

Chiswick, Barry R. and Paul W. Miller. 1998. "The Economic Cost to Native-Born Americans of Limited English Language Proficiency," Report prepared for the Center for Equal Opportunity, August.

Cobb-Clark, Deborah A. 1993. "Immigrant Selectivity and Wages: The Evidence for Women," American Economic Review 83: 986-993.

DaVanzo, Julie. 1976. "Difference between Return and Non-Return Migration: An Econometric Analysis," International Migration Review 10: 13-27.

DaVanzo, Julie. 1983. "Repeat Migration in the United States: Who Moves Back and Who Moves On?" Review of Economics and Statistics 65: 552-559.

DaVanzo, Julie and P. Morrison. 1986. “The Prism of Migration: Dissimilarities Between Return and Onward Movers," Social Science Quarterly 67: 113-126.

Duleep, Harriet O. and Mark C. Regets. 1996. "The Elusive Concept of Immigrant Quality: Evidence from 1970-1990,” Discussion Paper PRIP-UI-41, Program for Research on Immigration Policy. Washington, D.C.: Urban Institute.

Duleep, Harriet O. and Mark C. Regets. 1997a. "Measuring Immigrant Wage Growth Using Matched CPS Files," Demography 34: 239-249. 
Duleep, Harriet O. and Mark C. Regets. 1997b. "The Decline in Immigrant Entry Earnings: Less Transferable Skills or Lower Ability?" Quarterly Review of Economics and Finance 37 (Special Issue on Immigration): 89-208.

Finifter, Ada W. 1976. “American Emigration,” Society 13: 30-36.

Gabriel, Paul E. and Susanne Schmitz. 1995. "Favorable Self-Selection and the Internal Migration of Young White Males in the United States," Journal of Human Resources 30: 460471.

Herzog, Henry W. and Alan M. Schlottmann. 1983. "Migrant Information, Job Search and the Remigration Decision," Southern Economic Journal 50: 43-51.

Hirshleifer, Jack. 1958. "On the Theory of Optimal Investment Decisions," Journal of Political Economy 66: 329-352.

Islam, Muhammed N. and Saud A. Choudhury. 1990. "Self Selection and Interprovincial Migration in Canada," Regional Science and Urban Economics 20:459-472.

Jasso, Guillermina and Mark R. Rosenzweig. 1990. "Self-Selection and the Earnings of Immigrants: Comment," American Economic Review 80: 298-304.

Katz, Eliakim and Oded Stark. 1984. "Migration and Asymmetric Information: Comment," American Economic Review 74:533-534.

Katz, Eliakim and Oded Stark. 1987. "International Migration under Asymmetric Information," Economic Journal 97 (387):718-726.

Khan, Aliya H. 1997. "Post-migration Investments in Education by Immigrants in the United States," Quarterly Review of Economics and Finance 37 (Special Issue on Immigration): 285313.

Kossoudji, Sherrie A. and Deborah A. Cobb-Clark. 1998. "Coming Out of the Shadows: Learning About Legal Status and Wages From the Legalized Population," Department of Economics and School of Social Work, University of Michigan, xerox.

LaLonde, Robert J., and Robert H. Topel. 1992. "The Assimilation of Immigrants in the U.S. Labor Market," IN George J. Borjas \& Richard B. Freeman, eds., Immigration and the Work Force: Economic Consequences for the United States and Source Areas, Pp. 67-92. Chicago: University of Chicago Press.

Lindstrom, David and Douglas Massey. 1994. "Selective Emigration, Cohort Quality and Models 
of Immigrant Assimilation," Social Science Research 23: 325-349.

Long, Larry H. 1974. "Poverty Status and Receipt of Welfare Among Migrants and Nonmigrants in Larger Cities," American Sociological Review 39 (1): 46-56.

Long, Larry H. and Kristin A. Hansen. 1977. "Selectivity of Black Return Migration to the South," Rural Sociology 42 (3): 317-331.

Long, Larry H. and Lynne R. Heltman. 1975. "Migration and Income Differences Between Black and White Men in the North," American Journal of Sociology 80 (6): 1391-1409.

Masters, Stanley H. 1972. "Are Black Men from the South to the Northern Cities Worse Off then Blacks Already There?" Journal of Human Resources 7: 441-423.

Mincer, Jacob. 1978. "Family Migration Decisions,” Journal of Political Economy 86:749-773.

Rivera-Batiz, Francisco L. 1999. "Undocumented Workers in the Labor Market: An Analysis of the Earnings of Legal and Illegal Mexican Immigrants in the United States," Journal of Population Economics 12: 91-116.

Robinson, Chris and Nigel Tomes. 1982. "Self Selection and Interprovincial Migration in Canada," Canadian Journal of Economics 15: 474-502.

Rogers, Rosemarie. 1982. "Return Migration in Comparative Perspective," Fletcher School of Law and Diplomacy, Tufts University, mimeo.

Roy, A.D. 1951. "Some Thoughts in the Distribution of Earnings," Oxford Economic Papers 3: $135-46$.

Schultz, Theodore W. 1975. "The Value of the Ability to Deal with Disequilibrium," Journal of Economic Literature 13: 827-846.

Schwartz, Aba. 1973. "Interpreting the Effect of Distance on Migration," Journal of Political Economy 81: 1153-1169.

Schwartz, Aba. 1976. "Migration, Age, and Education," Journal of Political Economy 84: 701720.

Shumway, J. Matthew and Greg Hall. 1996. "Self Selection, Earnings and Chicano Migration: Differences Between Return and Onward Migrants," International Migration Review 30: 979994. 
Sjaastad, Larry A. 1962. "The Costs and Returns of Human Migration," Journal of Political Economy 70 (Supplement): 80-93.

Tidrick, Kathryn. 1971. "Need for Achievement, Social Class and Intention to Emigrate in Jamaican Students," Social and Economic Studies 20: 52-60.

Vandercamp, John. 1972. "Return Migration: Its Significance and Behavior," Western Economic Journal 10: 400-465.

Yezer, Anthony M. and L. Thurston. 1976. "Migration Patterns and Income Change: Implications for the Human Capital Approach to Migration," Southern Economic Journal 42: 693-702. 


\section{IZA Discussion Papers}

\section{No. Author(s)}

31

C. M. Schmidt

32

S.- Å. Dahl

$\varnothing$. A. Nilsen

K. Vaage

33

A. Lindbeck

D. J. Snower

34

P. A. Puhani

D. A. Jaeger

A. Huff Stevens

36

C. Lauer

37

H. S. Buscher

C. Müller

M. E. Ward

P. J. Sloane
A. Lindbeck

D. J. Snower

40

S. M. Golder

T. Straubhaar

J. M. Orszag

D. J. Snower

42

D. S. Hamermesh

43

C. Belzil

J. Hansen

44

D. N. F. Bell

R. A. Hart

45

R. A. Hart

J. R. Malley

46
Title

Persistence and the German Unemployment Problem: Empirical Evidence on German Labor Market Flows

Work or Retirement? Exit Routes for Norwegian Elderly

Price Dynamics and Production Lags

Labour Mobility - An Adjustment Mechanism in Euroland?

Is Job Stability in the United States Falling? Reconciling Trends in the Current Population Survey and Panel Study of Income Dynamics

The Effects of European Economic and Monetary Union on Wage Behaviour

Exchange Rate Volatility Effects on the German Labour Market: A Survey of Recent Results and Extensions

Job Satisfaction within the Scottish Academic Profession

Multi-Task Learning and the Reorganization of Work

Empirical Findings on the Swiss Migration Experience

Anatomy of Policy Complementarities

The Changing Distribution of Job Satisfaction

Household Characteristics, Ability and Education:

Evidence from a Dynamic Expected Utility Model

Overtime Working in an Unregulated Labour Market

On the Cyclicality and Stability of Real Earnings 1

The Effects of Development on Migration: Theoretical Issues and New Empirical Evidence
Area Date

$1 / 7$ 2/99

$3 / 7$ 2/99 
Overtime Work and Overtime Compensation in

Unemployment and Labor-Market Reform: A

Ethnic German Migration After 1989 - Balance 1 and Perspectives

51 A. Barrett

P. J. O'Connell

Does Training Generally Work?

Self-Employment Decision of Immigrant

Entrepreneurs

\section{5 \\ L. Goerke}
A. Lindbeck

D. J. Snower

I. N. Gang

K. F. Zimmermann

T. Bauer

K. F. Zimmermann

D. J. DeVoretz

S. A. Laryea

60

C. Belzil

J. Hansen

61

R. Winkelmann

62
A. Thalmaier

63

M. Ward

64

M. Ward

65
H. Lehmann
J. Wadsworth
A. Acquisti

Value-added Tax versus Social Security Contributions

Centralized Bargaining and Reorganized Work: $\quad 1 / 5 \quad$ 9/99 Are they compatible?

Is Child like Parent?

Educational Attainment and Ethnic Origin

Occupational Mobility of Ethnic Migrants

Canadian Immigration Experience:

Any Lessons for Europe?

Subjective Discount Rates, Intergenerational

Bestimmungsgründe von Fehlzeiten: Welche

4



and the former Soviet Union to Germany: the Effects of Migrant Networks

Are Austrian Returns to Education Falling Over

Adjustment Dynamics and the Natural Rate: An 1

Endogenous Schooling and the Distribution of the Gender Wage Gap

Entrepreneurship from Scratch: Lessons on the Entry Decision into Self-Employment from Transition Economies

81 T. J. Hatton

The Netherlands: Old Emigrants - Young Immigrant Country

Migration, Migrants and Policy in the United 
Tenures that Shook the World: Worker Turnover in Russia, Poland and Britain

Identification and Estimation of Causal Effects of

$\begin{array}{ll}92 & \text { R. E. Wright } \\ 93 & \text { M. Lechner }\end{array}$

P. Cahuc A. Zylberberg

P. Cahuc

A. Zylberberg

97

A. Barrett

L. Husted

H. S. Nielsen

M. Rosholm

N. Smith

102 B. van der Klaauw

J. C. van Ours
The Rate of Return to Private Schooling

An Evaluation of Public-Sector-Sponsored Continuous Vocational Training Programs in East Germany

An Evaluation of Public Employment Programmes in the East German State of Sachsen-Anhalt

Job Protection, Minimum Wage and Unemployment 3

Redundancy Payments, Incomplete Labor Contracts, Unemployment and Welfare 
Matching Model with Uncertainty -

An Extension of Mortensen and Pissarides (1994)

Job Tenure of Two Cohorts of Young German Men

107 J. C. van Ours G. Ridder

J. Boone

J. C. van Ours

109 G. J. van den Berg

$B$. van der Klaauw

110 D. DeVoretz

C. Werner

V. Sorm

K. Terrell

\section{Bellmann}

T. Schank

113 R. Euwals

114 G. Brunello

A. Medio

115 A. Cigno

F. C. Rosati

116

C. Belzil

119 A. Lindbeck D. J. Snower

120 P. T. Pereira P. S. Martins
Fast Track or Failure: A Study of the Completion Rates of Graduate Students in Economics

Modeling Financial Incentives to Get Unemployed Back to Work

Combining Micro and Macro Unemployment

Duration Data

A Theory of Social Forces and Immigrant Second

Sectoral Restructuring and Labor Mobility:

A Comparative Look at the Czech Republic

Innovations, Wages and Demand for

Heterogeneous Labour: New Evidence from a

Matched Employer-Employee Data-Set

Do Mandatory Pensions Decrease Household

Savings? Evidence for the Netherlands

An Explanation of International Differences in

Education and Workplace Training

Why do Indian Children Work, and is it Bad for

7

Them?

Unemployment Insurance and Subsequent Job

7

Duration: Job Matching vs. Unobserved

Heterogeneity

IAB Employment Subsample 1975-1995.

Opportunities for Analysis Provided by the

Anonymised Subsample

Improving Nurse Retention in the British National Health Service: The Impact of Job Satisfaction on Intentions to Quit

The Division of Labor and the Market for

Organizations

Does Education Reduce Wage Inequality? 
122 D. Munich

J. Svejnar

K. Terrell

123 J. Hunt

124 R. T. Riphahn

125 F. Büchel

J. R. Frick

126 J. Fersterer

R. Winter-Ebmer

127 M. Karanassou

D. J. Snower

128

O. Ashenfelter

D. Ashmore

O. Deschênes

129 B. R. Chiswick

M. E. Hurst

130 G. Brunello

S. Comi

C. Lucifora

131 B. R. Chiswick
Returns to Human Capital under the Communist

4

Wage Grid and During the Transition to a Market

Economy

Why Do People Still Live in East Germany?

1

$3 / 00$

Rational Poverty or Poor Rationality? The Take-up 3

of Social Assistance Benefits

The Income Portfolio of Immigrants in Germany -

$1 / 3$

$3 / 00$

Effects of Ethnic Origin and Assimilation. Or:

Who Gains from Income Re-Distribution?

Smoking, Discount Rates, and Returns to

$6 / 7 \quad 3 / 00$

Education

Characteristics of Unemployment Dynamics: The

Chain Reaction Approach

Do Unemployment Insurance Recipients Actively

Seek Work? Evidence From Randomized Trials in

Four U.S. States

The Employment, Unemployment and

Unemployment Compensation Benefits of

$1 / 3 \quad 3 / 00$

Immigrants

The Returns to Education in Italy: A New Look at the Evidence

$5 / 7$

Are Immigrants Favorably Self-Selected? An

Economic Analysis
$3 / 00$

$3 / 00$

$3 / 00$

$3 / 00$

$3 / 00$

An updated list of IZA Discussion Papers is available on the center's homepage www.iza.org. 